\author{
Aldona MIGALA-WARCHOL ${ }^{1}$ \\ Paweł HYDZIK ${ }^{2}$ \\ Marek SOBOLEWSKI ${ }^{3}$
}

\title{
THE ANALYSIS OF CHANGES IN MORTALITY IN TRAFFIC IN THE EUROPEAN UNION COUNTRIES IN THE PERIOD 1991-2011
}

\begin{abstract}
The article presents the results of time-space analysis of selected aspects of road safety in the European Union countries. The study horizon covered years 1991-2011. Data for the analysis were obtained from the databases of Eurostat and related to the number of accidents and the number of people killed and injured in road accidents. The raw values of these attributes were converted into intensity rates against the number of inhabitants. The rest of the work presents in a graphical form the rankings of EU countries according to road safety in 2011 based on the rate of accidents, injuries and the killed in terms of the number of inhabitants. Since the rankings were characterized by a very low similarity of results, it was made a critical assessment of the reliability of data on the number of accidents and the number of people injured published by EUROSTAT. In particular, it was shown that these data are not comparable and cannot be the subject of thorough international analysis. The reason for this fact are significant differences in the definition of persons injured and hence the accident. We can draw an important conclusion that all international comparisons must be based on the index number of people killed in road accidents. Taking into account the temporal aspect of the studied phenomenon, for each country it was determined the direction and rate of change indicator of the killed in accidents in the years 1991-2011 using the linear trend models. In a more detail way it was analyzed the level of road safety in Poland and neighboring countries - Germany, Slovakia, the Czech Republic and Lithuania.
\end{abstract}

Keywords: road safety, time-space analysis, ratings.

\section{INTRODUCTION}

Road accidents are the major cause of deaths of young people in most European countries. Apart from the direct social and economic effects road accidents also have indirect effects on many negative phenomena - such as escalation of demographic crisis in the European Union countries. In 2011, in 27 Member States of the European Union nearly 31 thousand of people were killed on the road. In the study period of this work so in the years 1991-2011, more than 1,1 million people were killed on the EU roads.

\footnotetext{
${ }^{1}$ Aldona Migała-Warchoł, PhD, Department of Quantitative Methods, Faculty of Management, The Rzeszow University of Technology, Rzeszow, al. Powstańców Warszawy 8, 35-959 Rzeszów, tel. 17 8651894, e-mail: amigala@ prz.edu.pl (Corresponding Author).

${ }^{2}$ Paweł Hydzik, PhD, Department of Quantitative Methods, Faculty of Management, The Rzeszow University of Technology, Rzeszow, al. Powstańców Warszawy 8, 35-959 Rzeszów, tel. 17 8651894, e-mail: phydzik@prz.edu.pl.

${ }^{3}$ Marek Sobolewski, PhD, Department of Quantitative Methods, Faculty of Management, The Rzeszow University of Technology, Rzeszow, al. Powstańców Warszawy 8, 35-959 Rzeszów, tel. 17 8651894, e-mail: msobolew@ prz.edu.pl.
} 
The country in which the most people were killed in road accidents in 2011, was Poland (in total number it was 4189 people, while the rate of road fatalities per 1 million of inhabitants was 109, which placed Poland in second place among the European Union countries). For the meantime, the analysis of variability in the number and effects of road accidents in Poland leads to some optimistic conclusions - every year they are becoming less and less [Sobolewski 2012]. To explain these pieces of seemingly conflicting information, it is necessary to carry out a comparative analysis of the diversity of road safety in Poland and other European countries, taking into account the time factor.

The basic test, the results of which are presented in this work, is the analysis of spatial differentiation of road accidents risk in the particular countries of the European Union. For this purpose, the relative rate of fatalities, in which the reference point was the number of inhabitants, was used. European Union countries are very much different in terms of the level of this rate. In 2011, it was the highest in Greece (111 fatalities per million inhabitants), and the lowest in Great Britain (statistically 31 people on million inhabitants died in road accidents, which is almost four times less than in Greece!). Because of the fact that the risk of road accidents in the European Union countries is so much varied, the issue of variability of such phenomenon over time naturally arises. The following work also contains the answer to such a question, by making a detailed analysis of the dynamic rate of people killed in road accidents in the period 1991-2011 at the level of each country.

In the subsections two and three basic information about the definitions of road accidents in the European Union countries as well as the social and economic costs of these occurrences have been shown. Next, there have been presented the data source from which the material for statistical analysis was used. Subsection four deals with an interesting issue concerning data of number of accidents, injured and those who died in those accidents being linked together. Here what is particularly important is the issue of comparability of international data because without such a condition, any spatial analysis has no practical sense. The fifth part of the work presents a detailed analysis of the variability rate of those killed in road accidents in the years 1991-2011 in each European Union country. The work ends with a conclusion in which the directions for further researches have been outlined.

\section{DEFINITIONS OF 'ACCIDENT' IN POLAND AND IN THE EUROPEAN UNION}

Definitions of security incidents on the roads in various countries of the European Union are varied. Thus, in order to obtain comparability of statistics concerning road safety, an extensive discussion, which involves experts profession, the European Commission and the European Parliament ${ }^{4}$ have been conducted. The European Union, in order to harmonize the statistics from different countries, in the years 2012-2013 has taken several steps towards the adoption of a consistent system for defining the circumstances and occurrences related to road accidents ${ }^{5}$. Thus, from 2014 a new consistent definition, which will allow to use common statistics, will be used. In addition, the objective of

\footnotetext{
${ }^{4}$ http://www.krbrd.gov.pl/aktualnosci/Parlament_Europejski_o_brd.htm http://edroga.pl/inzynieria-ruchu/brd/ 8110-ke-strategia-w-zakresie-zapobiegania-powaznym-obrazeniom-odniesionym-w-wypadkach-drogowych-cz-i

${ }^{5}$ http://ec.europa.eu/transport/road_safety/topics/serious_injuries/index_pl.htm
} 
reducing the number of serious injuries and the strategy enabling its fulfilling has been taken. As far as gathering statistical data is concerned, it has been recommended that in the European Union countries there is a need to use one of these methods:

- combining data from hospital documents with the ones from the police;

- using only data from hospital;

- using police data with the margin of error, as the result of which the statistics of number of fatalities are underestimated.

The announcement of European Commission concerning road safety for the years 2011-2020 has obtained the support of the European Parliament in the form of a resolution from 27 September $2011^{6}$, which supported the objective of reducing the number of fatalities by $50 \%$ by 2020. In addition, the social costs of road accidents in the EU amounting to 130 billion Euro per year were stated and determining the following objectives had been suggested:

- $60 \%$ reduction in fatalities among children under the age of 14 ;

- $50 \%$ reduction in causalities among pedestrians and cyclists;

- $40 \%$ reduction in the number of seriously injured people with the regard of adoption of a consistent definition of an injured person in the European Union countries. ${ }^{7}$

According to the Central Statistical Office "a road accident is an occurrence associated with the movement of vehicles on public road, which resulted in the death or injury of people's body. A road accident fatality is a person who died as a result of his injuries on the spot or within 30 days. A wounded casualty of road accident is a person who has suffered body injuries and received medical help"

However, in the Eurostat documents ${ }^{9}$ the following definition of road accident has been presented: „An accident with the victims is the accident which involves at least one road vehicle in movement on public road or the private one with the right of access for the general population, as a result of which at least one person is injured or killed. Suicide or its attempt is not an accident but the incident caused by a deliberate act aimed at personal injury resulting in death. However, if as a result of suicide or its attempt some other road user suffers, then such an incident is considered to be an accident with casualties. Here, there can be included: road vehicles collisions, collisions with pedestrians and road vehicles with the participation of road vehicles and animals or fixed obstacles and with the participation of only one road vehicle. Collisions involving road and rail vehicles are also taken into consideration. Collisions involving many vehicles are considered as only one accident if further collisions take place in a very short period of time. Accidents with victims do not include accidents that end only with material loss. Terrorist attacks are precluded. As to „the fatality”, it is a road accident in which there is a fatality. The casualty of accident is a person killed or injured as a result of road accident".

\footnotetext{
${ }^{6} \mathrm{http}: / /$ www.europarl.europa.eu/sides/getDoc.do?pubRef=-//EP//TEXT+TA+P7-TA-2011$0408+0+\mathrm{DOC}+\mathrm{XML}+\mathrm{V} 0 / / \mathrm{EN} \&$ language $=\mathrm{EN}$

${ }^{7}$ http://edroga.pl/inzynieria-ruchu/brd/8110-ke-strategia-w-zakresie-zapobiegania-powaznym-obrazeniomodniesionym-w-wypadkach-drogowych-cz-i

${ }^{8} \mathrm{http}: / /$ www.stat.gov.pl/gus/definicje_PLK_HTML.htm?id=POJ-3289.htm

${ }^{9} \mathrm{http}: / /$ ec.europa.eu/eurostat/ramon/coded_files/transport_glossary_4_ed_PL.pdf
} 


\section{SOCIOECONOMIC COSTS OF ROAD ACCIDENTS}

According to one of the earliest European Commission's guidelines on the subject of evaluation in the category of the costs of transport, the following main categories of unit costs of road accidents are being recognized:

- medical costs;

- the costs of lost productive capacity (lost production);

- the assessment of the lost quality of life (the loss of goods due to accidents);

- the costs of the property damage;

- the administrative costs.

With the development of research in this direction, the issue of the costs of road accidents has been expanded with new elements, including road collisions. Therefore, in terms of the valuation of the social consequences of road traffic, the valuation of the costs of road accidents according to the following formula have been recommended [JaździkOsmólska 2012]:

where:

$$
K_{z d r}=K_{b p s}+K_{b p r}+K_{p s r}+K_{k o l}+K_{d o d}
$$

$\mathrm{K}_{\mathrm{zdr}}$ - the costs of road accidents,

$\mathrm{K}_{\mathrm{bps}}$ - the security costs per se,

$\mathrm{K}_{\mathrm{bpr}}$ - the direct costs of accidents (direct economic costs),

$\mathrm{K}_{\mathrm{psr}}$ - the indirect costs of accidents (indirect economic costs),

$\mathrm{K}_{\mathrm{kol}}$ - the costs of collision,

$\mathrm{K}_{\mathrm{dod}}-$ additional costs.

The major direct costs of accidents are:

- medical and rehabilitation costs are the ones associated with the period of the patient's working disability;

- the administrative costs of the accident which include: the costs of police investigation concerning the accident, legal costs and administrative costs of insurance;

- the costs of emergency services concerning emergency assistance;

- the costs of damage to property which include damage to the vehicle and the equipment of the road.

The indirect economic costs can be defined as the lost Gross Domestic Products as a result of premature death and disability to work of the injured due to an accident.

All the costs which were mentioned are not able to convey and balance the tragedy of the casualty, aggrieved and their families. In Poland (as well as in many other countries) apart from the overall statistics, we know practically nothing about the casualties of road accidents. What happens with people who lose their jobs as a result of accident or have to change it for much worse? What happens with the families of fatalities deprived of the main breadwinner as a result of accident?

The losses generated by road incidents have definitely a negative impact on the quality of life of a society. Not only are they the causes of many tragedies but also have a certain economic dimension reflecting adversely on the financial possibilities of the country. As far as Poland is concerned, these losses can be estimated in tens of billions (zloty), 
slowing the economic opportunities and at the same time increasing the financial encumbrance of citizens [Popiel 2012] ${ }^{10}$.

The calculation of accidents costs in case of economy should be an impetus for the authorities to take further steps to increase safety on the roads. According to the recommendation of the $\mathrm{WHO}$, in order to increase road safety in Poland, it is necessary to enforce regulations concerning speed limits in much efficient way. On the other hand, the organization highlights good enforcement of regulations concerning prohibition of driving under the influence of alcohol.

\section{DATA SOURCES AND THE METHODS OF MEASUREMENT OF POTENTIAL ACCIDENTS}

The analysis was based on data concerning 27 Member States of the European Union (according to the state from the beginning of 2013) about the number of injured and killed in road accidents, which were obtained from the Eurostat sites. This data was supplemented by information on the number of accidents which are available on the UNO. The time horizon of the analysis covered the period of 1991-2011.

In order to enable the comparison of data for countries of different size, rough values for the number of accidents, people injured and killed had been related to the population, defining thereby three rates:

- the rate of the number of accidents per million inhabitants;

- the rate of the number of injured per million inhabitants;

- the rate of the number of fatalities per million inhabitants.

The rate of the number of people killed in accidents seems to be the best to describe a complex phenomenon known as ,the level of road safety”. This rate cumulates information about the number of accidents and their severity, the effectiveness of lifesaving system, etc. On the other hand, considering benefits from the economic point of view, the number of people being injured is strongly associated with the financial consequences of accidents because not only fatal accidents generate such costs. In the next section information about the spatial distribution of the values of all three rates in 2003 defined below will be provided. Correlations between these rates will be also explored and the issues of accordance in case of definitions being analyzed in this work will be mentioned.

The basic variables describing the level of road safety are: the number of accidents, the number of people injured and the number of fatalities. Of course, the analysis of international data require bringing rough values to comparability, which were obtained by converting them into a million inhabitants. The next sections present the spatial distribution of rates obtained in this way in the European Union countries in 2011.

First, however, it was decided to check the accordance of the information about the level of road safety in the individual rates. For this purpose, the values of Spearman's rank correlation coefficients, by which we can assess the accordance of the country's orderliness of each rate, was calculated (Table 1).

\footnotetext{
${ }^{10}$ Estimated losses caused by the number of road fatalities in Poland, according to the World Bank in 2009 amounted to 12.8 billion zloty, in $2010-10.9$ billion zloty, while in 2011 increased to 11.7 billion zloty.
} 
The results are surprising. It turns out that there is a very high correlation between the intensity rates for the number of accidents and injuries, but none of them is related to the rate of the number of killed in road accidents.

Table 1. Correlations between the values of the rates of number of accidents, injuries and killed (2011)

\begin{tabular}{|c|c|c|c|}
\hline $\begin{array}{c}\text { The results of } \\
\text { correlation } \\
\text { analysis }\end{array}$ & The rate of accidents & The rate of injured & The rate of killed \\
\hline $\begin{array}{c}\text { The rate of } \\
\text { accidents }\end{array}$ & $\times$ & $R=0,90(p=0,0000 * * *)$ & $R=-0,03(p=0,8990)$ \\
\hline The rate of injured & $R=0,90(p=0,0000 * * *)$ & $\times$ & $R=-0,16(p=0,4184)$ \\
\hline The rate of killed & $R=-0,03(p=0,8990)$ & $R=-0,16(p=0,4184)$ & $\times$ \\
\hline
\end{tabular}

$R$ - Spearman's rank correlation coefficient, $p$ - test probability

Source: own study

Figure 1 shows the spatial distribution of the rate of the number of road accidents whereas Figure 2 and 3 present analogical rates concerning the number of injured and killed in accidents. Comparison of the values of number of accidents and injured rates with the values of killed leads to surprising conclusions, which could be expected after the recognition of the complete lack of correlation between these values.

For example, the number of injured per million inhabitants is the highest in Belgium, and Austria. It is also high in Germany, Luxemburg and Italy (Fig. 2). The presented territorial distribution of this rate is different from the spatial differentiation rate of road casualties (Fig. 3). These discrepancies are so large that it is difficult to explain them in a rational way. Indeed, the level of road life-saving and health services remain at a much lower level in the Eastern European countries which may result in the fact that the rate of the number of people being killed to the ones being injured is higher in these countries. However, it does not explain such huge differences, especially as they also relate to the Western European countries (in the Netherlands the rate of the number of injured is almost ten times lower than in neighboring Belgium!). 
Figure 1. The differentiation of the rate of the number of road accidents in the EU countries in 2011

The rate of accidents per million inhabitants (2011)

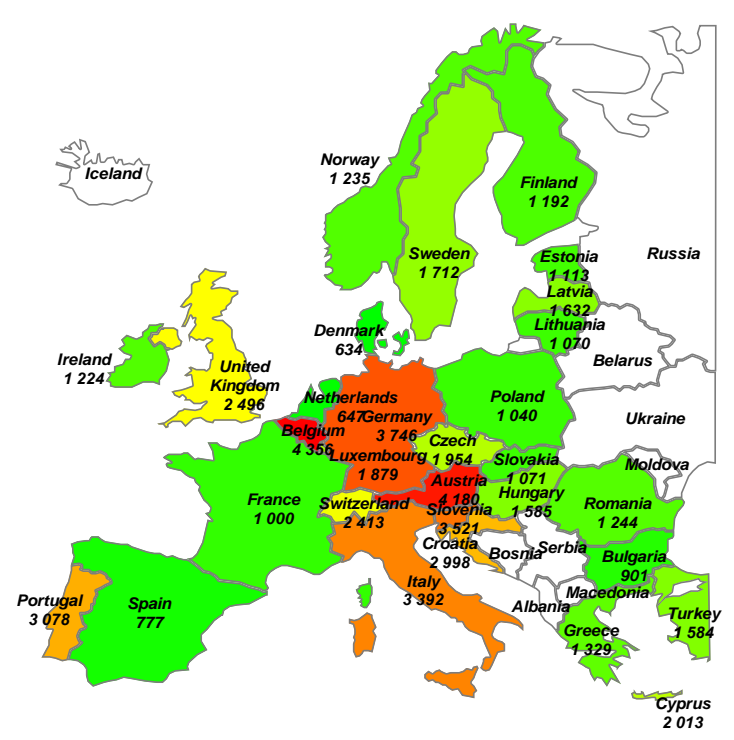

Source: own study

Figure 2. The differentiation of the rate of the number of injured in road accidents in the EU countries in 2011

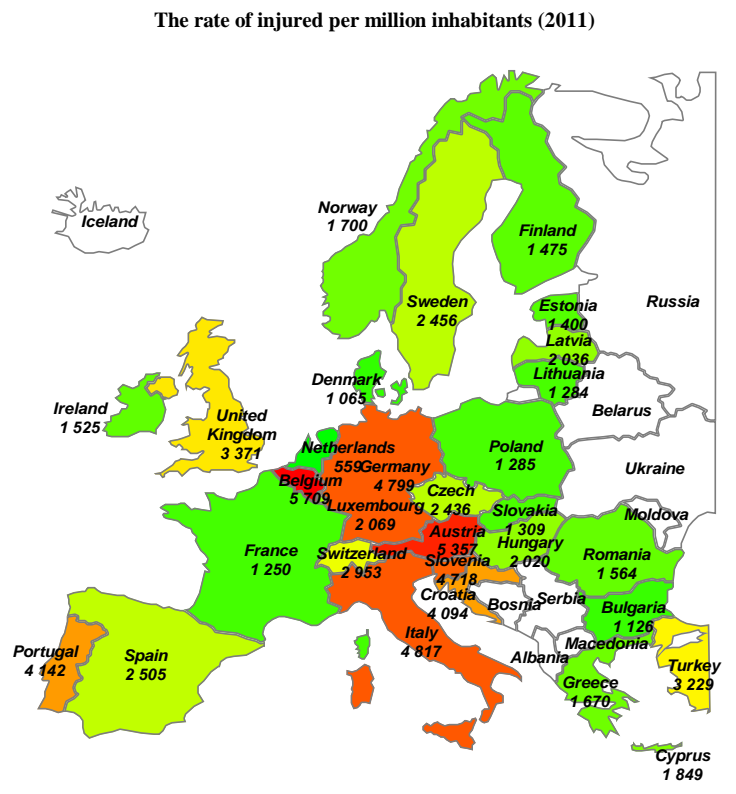

Source: own study 
It seems that there are two issues of the real reason for such a huge differentiation in the rate level of the people injured in road accidents - firstly, the differences in the definition of a person injured in the road accident, secondly, the tendency of not reporting to the police parts of the road incidents in some countries. The second factor is, however, probably of marginal importance, so it is worth to look closer at the definitional differences that occur in the European Union countries ${ }^{11}$. At this point we will stop for acknowledgment of the fact that the substantive value of the data concerning the number of injured and the number of accidents is very small and, therefore, all further analysis will be based only on the rate of the number of fatalities ${ }^{12}$.

Figure 3. The differentiation of the rate of the number of casualties in road accidents in the EU countries in 2011

The rate of casualties per million inhabitants (2011)

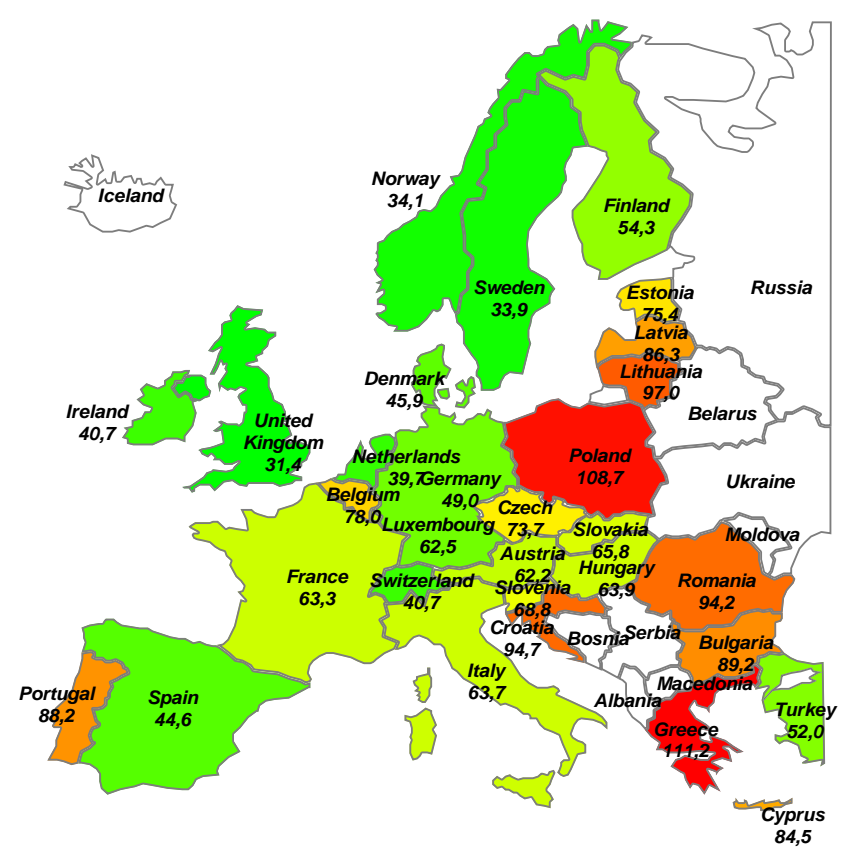

Source: own study

\footnotetext{
${ }^{11}$ The issue will be thoroughly presented in the monograph on road safety in an international aspect which is planned to be released by the authors in 2014 .

${ }^{12}$ It is worth mentioning that the European Union has taken a number of measures to harmonize statistics from different countries in 2012-2013, which would be possible after the adoption of consistent system for defining the circumstances and incidents related to road accidents.
} 


\section{CHANGES IN THE NUMBER OF ROAD CASUALTIES IN THE EUROPEAN UNION COUNTRIES 1991-2011}

In this part of the work, the analysis of the risk of road accidents will be extended for the time dimension. The rate of the number of road accidents casualties per million inhabitants will be the subject of the analysis. Below, (Table 2) there have been placed the information concerning the minimum and maximum value of this rate in the European Union countries in particular years, and the mean value as well as median and classical coefficient of variation have been given. The complement of information about the distribution of the rate of the number of killed in individual countries is the total number of road casualties in the whole European Union.

Table 2. The characteristics of the distribution of the number of road fatalities rate in the EU countries for the years covered by the analysis

\begin{tabular}{|c|c|c|c|c|c|c|}
\hline \multirow{2}{*}{ Year } & \multirow{2}{*}{$\begin{array}{c}\text { The total number } \\
\text { of casualties in } \\
\text { the EU }\end{array}$} & \multicolumn{4}{|c|}{ The number of killed per million inhabitants } \\
\cline { 3 - 7 } & 75 & Me & $\min$ & $\max$ & $V$ \\
\hline $\mathbf{1 9 9 1}$ & 706 & 178,5 & 166,3 & 44,1 & 385,6 & $46,7 \%$ \\
\hline $\mathbf{1 9 9 2}$ & 70731 & 163,8 & 166,0 & 30,3 & 309,4 & $39,7 \%$ \\
\hline $\mathbf{1 9 9 3}$ & 65441 & 156,3 & 161,9 & 38,6 & 280,0 & $40,2 \%$ \\
\hline $\mathbf{1 9 9 4}$ & 63903 & 154,5 & 156,7 & 16,4 & 304,6 & $42,5 \%$ \\
\hline $\mathbf{1 9 9 5}$ & 63155 & 149,4 & 150,0 & 37,9 & 270,6 & $38,9 \%$ \\
\hline $\mathbf{1 9 9 6}$ & 59409 & 138,9 & 132,7 & 51,2 & 271,8 & $38,4 \%$ \\
\hline $\mathbf{1 9 9 7}$ & 60267 & 140,1 & 138,7 & 48,1 & 250,3 & $37,1 \%$ \\
\hline $\mathbf{1 9 9 8}$ & 58982 & 138,4 & 133,4 & 45,2 & 279,7 & $40,3 \%$ \\
\hline $\mathbf{1 9 9 9}$ & 57691 & 132,7 & 135,2 & 10,6 & 271,8 & $40,4 \%$ \\
\hline $\mathbf{2 0 0 0}$ & 56427 & 130,1 & 124,0 & 39,5 & 266,6 & $37,3 \%$ \\
\hline $\mathbf{2 0 0 1}$ & 54302 & 124,0 & 124,6 & 40,9 & 236,0 & $35,3 \%$ \\
\hline $\mathbf{2 0 0 2}$ & 53342 & 121,9 & 124,6 & 40,5 & 238,3 & $35,6 \%$ \\
\hline $\mathbf{2 0 0 3}$ & 50351 & 115,0 & 118,2 & 40,3 & 228,2 & $36,4 \%$ \\
\hline $\mathbf{2 0 0 4}$ & 47290 & 112,2 & 112,1 & 32,5 & 222,5 & $40,4 \%$ \\
\hline $\mathbf{2 0 0 5}$ & 45346 & 107,6 & 104,3 & 42,2 & 225,7 & $39,6 \%$ \\
\hline $\mathbf{2 0 0 6}$ & 43104 & 102,5 & 96,5 & 27,2 & 223,3 & $42,9 \%$ \\
\hline $\mathbf{2 0 0 7}$ & 42540 & 104,0 & 96,6 & 34,3 & 218,6 & $42,1 \%$ \\
\hline $\mathbf{2 0 0 8}$ & 38941 & 90,3 & 83,4 & 36,6 & 148,2 & $38,5 \%$ \\
\hline $\mathbf{2 0 0 9}$ & 34814 & 78,5 & 75,8 & 37,9 & 130,1 & $35,5 \%$ \\
\hline $\mathbf{2 0 1 0}$ & 31029 & 67,6 & 67,4 & 28,5 & 111,3 & $35,9 \%$ \\
\hline $\mathbf{2 0 1 1}$ & 30751 & 67,3 & 63,9 & 31,4 & 111,2 & $33,5 \%$ \\
\hline
\end{tabular}

Source: own study

The following table (Table 3) presents the results of the analysis of linear trends for the accident rate in the period 1991-2011 for each of the analyzed countries. The countries had been ranked in the increasing order against the value of the regression coefficient $(B)$, starting from those where declines in road safety risks were the greatest. About the quality of the linear model matching to the value rate in the years 1991-2011 testifies the value of linear correlation coefficient $(r)$, and the addition of the analysis are the values of 
Spearman's correlation coefficient, which should allow to identify the presence of nonlinear trends. As we can see, for almost all the EU countries, except for Bulgaria, Romania, Malta and Slovakia we can say about fairly systematic with a huge linear approximation, the decline in the number of killed rate per one million inhabitants. In Portugal, the average annual rate of decline is 12.6 deaths per one million inhabitants, in Germany 4.6 and in Poland 3.8. The profound analysis should, however, rely on the connection of the rate of decline with the average level of the rate provided, therefore, the table contains its highest and lowest value in the whole analyzed period. In this context, the result for Poland is unfortunately one of the worst as no other country has such a low rate of decline with such a high value of the rate of killed.

Table 3. The analysis of variability rate of the number of killed in road accidents per million inhabitants in EU

\begin{tabular}{|c|c|c|c|c|c|}
\hline The EU countries & Min & $\operatorname{Max}$ & $\boldsymbol{R}_{\mathrm{S}}$ & $r$ & $\boldsymbol{B}$ \\
\hline Portugal & 79,0 & 322,5 & $-0,98 *$ & $-0,98^{*}$ & $-12,9$ \\
\hline Latvia & 86,3 & 385,6 & $-0,95 *$ & $-0,93^{*}$ & $-11,2$ \\
\hline Estonia & 58,2 & 324,2 & $-0,89 *$ & $-0,88^{*}$ & $-9,0$ \\
\hline Slovenia & 67,4 & 253,8 & $-0,94 *$ & $-0,95 *$ & $-8,6$ \\
\hline Spain & 44,6 & 225,8 & $-0,95 *$ & $-0,94^{*}$ & $-7,0$ \\
\hline France & 61,7 & 182,7 & $-0,99 *$ & $-0,98^{*}$ & $-6,6$ \\
\hline Luxembourg & 62,5 & 210,3 & $-0,93 *$ & $-0,94 *$ & $-6,6$ \\
\hline Cyprus & 73,2 & 213,2 & $-0,95 *$ & $-0,93 *$ & $-6,1$ \\
\hline Lithuania & 89,8 & 317,5 & $-0,55^{*}$ & $-0,71 *$ & $-6,0$ \\
\hline Austria & 62,2 & 196,8 & $-0,99 *$ & $-0,98^{*}$ & $-5,9$ \\
\hline Greece & 111,2 & 227,7 & $-0,96 *$ & $-0,95^{*}$ & $-5,4$ \\
\hline Belgium & 74,9 & 186,0 & $-0,94 *$ & $-0,96^{*}$ & $-4,9$ \\
\hline Hungary & 63,9 & 204,5 & $-0,88^{*}$ & $-0,88^{*}$ & $-4,9$ \\
\hline Germany & 44,6 & 139,5 & $-1,00 *$ & $-0,99 *$ & $-4,6$ \\
\hline Ireland & 40,7 & 129,4 & $-0,91 *$ & $-0,91 *$ & $-4,0$ \\
\hline Poland & 102,4 & 205,7 & $-0,91 *$ & $-0,90 *$ & $-3,8$ \\
\hline The Czech Republic & 73,7 & 158,4 & $-0,81 *$ & $-0,83^{*}$ & $-3,5$ \\
\hline Denmark & 45,9 & 117,0 & $-0,96 *$ & $-0,96^{*}$ & $-3,4$ \\
\hline Italy & 63,7 & 142,7 & $-0,92 *$ & $-0,92 *$ & $-3,4$ \\
\hline Finland & 50,8 & 125,0 & $-0,95 *$ & $-0,91 *$ & $-2,8$ \\
\hline The Netherlands & 32,4 & 86,5 & $-0,97 *$ & $-0,97 *$ & $-2,8$ \\
\hline Sweden & 28,5 & 87,3 & $-0,91 *$ & $-0,92 *$ & $-2,2$ \\
\hline Slovakia & 65,8 & 152,0 & $-0,53 *$ & $-0,61 *$ & $-2,1$ \\
\hline Great Britain & 30,7 & 82,4 & $-0,97 *$ & $-0,93^{*}$ & $-2,0$ \\
\hline Bulgaria & 89,2 & 164,3 & $-0,54 *$ & $-0,62 *$ & $-1,7$ \\
\hline Romania & 94,2 & 142,2 & $-0,26$ & $-0,31$ & $-0,6$ \\
\hline Malta & 10,6 & 51,2 & $-0,01$ & 0,09 & 0,2 \\
\hline
\end{tabular}

Min, max - the largest and the smallest values observed in the years 1991-2011

$R_{\mathrm{S}}$ - the value of Spearman's rank correlation coefficient with the assessment of statistical significance

$r$ - the value of linear correlation coefficient with the assessment of statistical significance

$B$ - the coefficient of directional linear trend 
Below, there is the „study” of selected cases ${ }^{13}$, showing the trajectory of changes in the number of killed per million inhabitants in Poland (Fig. 4) and in the European countries neighboring with Poland or lying nearby (Fig. 5 and 6) on the background of the whole population of EU countries.

Figure 4. The rate of those killed in Poland in the background of the European Union in the period 1991-2011

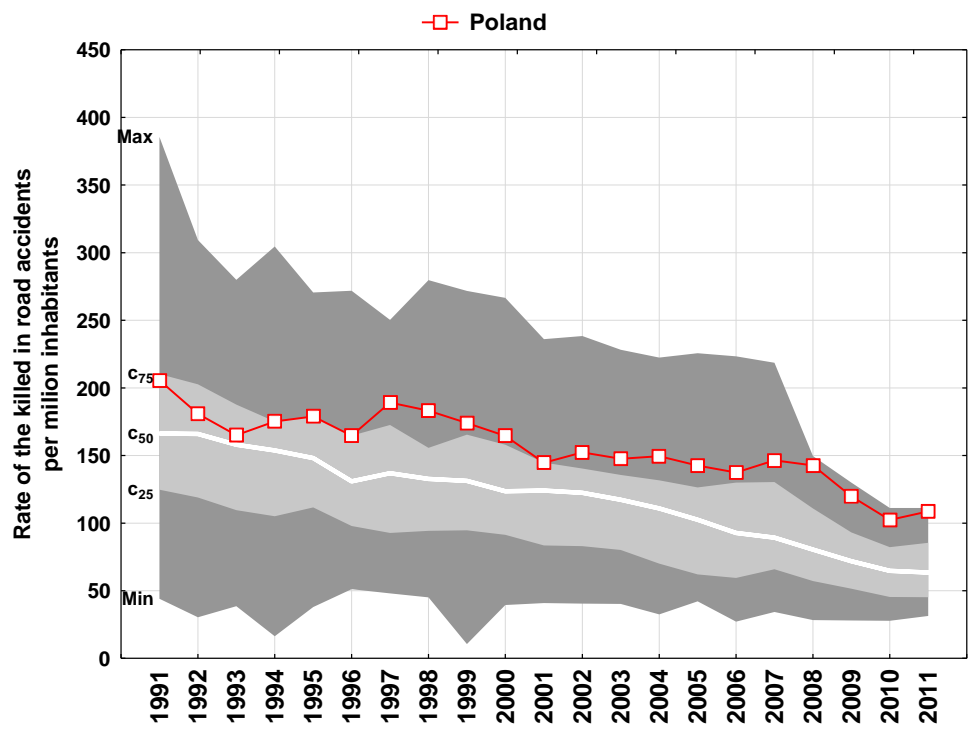

Source: own study

Analyzing the results obtained for both Poland and the EU countries we can observe that there is a downward trend. However, the values for Poland for the vast majority of years slightly exceed the $75^{\text {th }}$ percentile for the EU countries (with the exception of the years 1992-1993 when the rate of killed obtained the values at the level of $50^{\text {th }}$ percentile). For the past four analyzed years (2008-2011) its value was close to the maximum value of the EU countries.

\footnotetext{
${ }^{13}$ In subsequent publications similar detailed analysis will be carried out not only for all other EU countries but also at the level of EU regions (NUTS-2).
} 
Figure 5. The rate of the killed in the Baltic countries on the background of the EU in the period 1991-2011

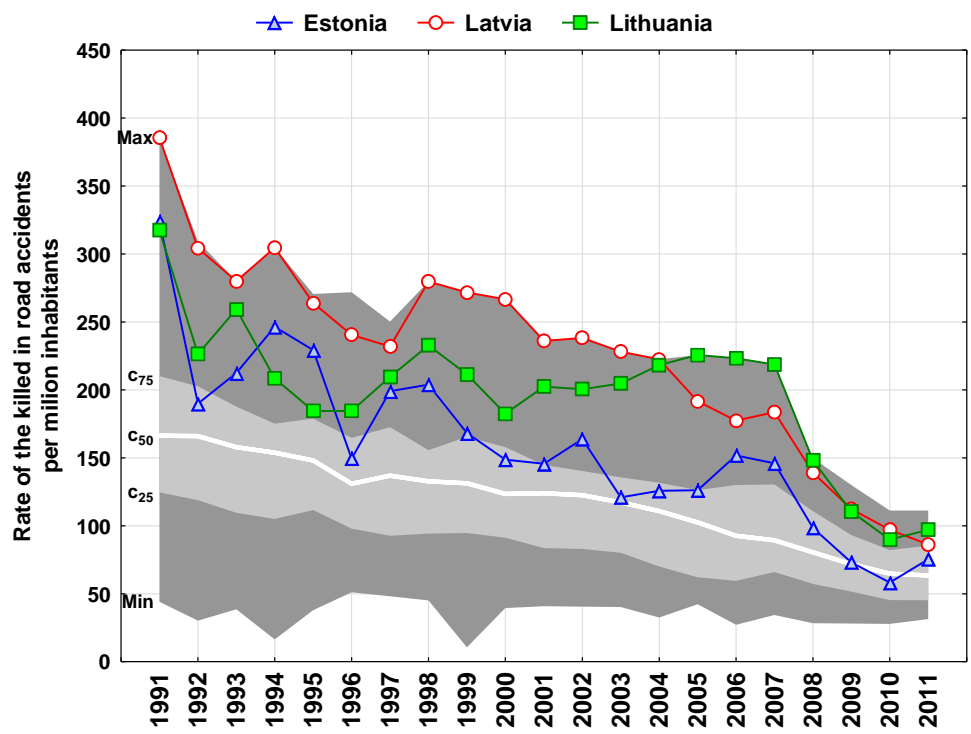

Source: own study

Analyzing data concerning the rate of killed in the Baltic countries it should be noticed that till the year 2004 the highest discussed rate marked Latvia and its value in the period from 1991 to 2004 for almost all the years hovered around the maximum value for the EU. After 2004 there is a strong decrease of these values, however, only in 2011 it reached the level of 75 th percentile of values for all EU countries. This country has improved the road safety also in relative terms with respect to changes in the whole European Union.

In the case of Lithuania, the situation was more diverse. Initially the discussed rate had the values between the 75th percentile and maximum value for the European Union countries. In 2004, approached the maximum value and remained until 2008. Then, we can observe the decrease of the rate of killed but it did not reach the value below the 75th percentile for the EU countries. Comparing the values obtained for all three analyzed countries it should be noticed that the values for Lithuania oscillated between the data for Estonia and Latvia (except for the two years 1994-1995 when Lithuania reached the lowest value of the three analyzed countries). In years 2005-2008 the country reached the highest value of the analyzed rate, like in 2011.

The lowest rate of people killed among three analyzed countries is Estonia (except for the two years 1994-1995 when the lowest values had Lithuania) however, the rate had the values of 75th percentile in comparison with the data concerning the EU (except for the years 1991, 1994-1995 and 1997-1998, when its value far exceeded this level). For 2010, the rate fell below the $50^{\text {th }}$ percentile. In 2011, its growth again can be observed. 
Figure 6. The rate of the killed in the Czech Republic, Germany and Slovakia on the background of the European Union in the period 1991-2011

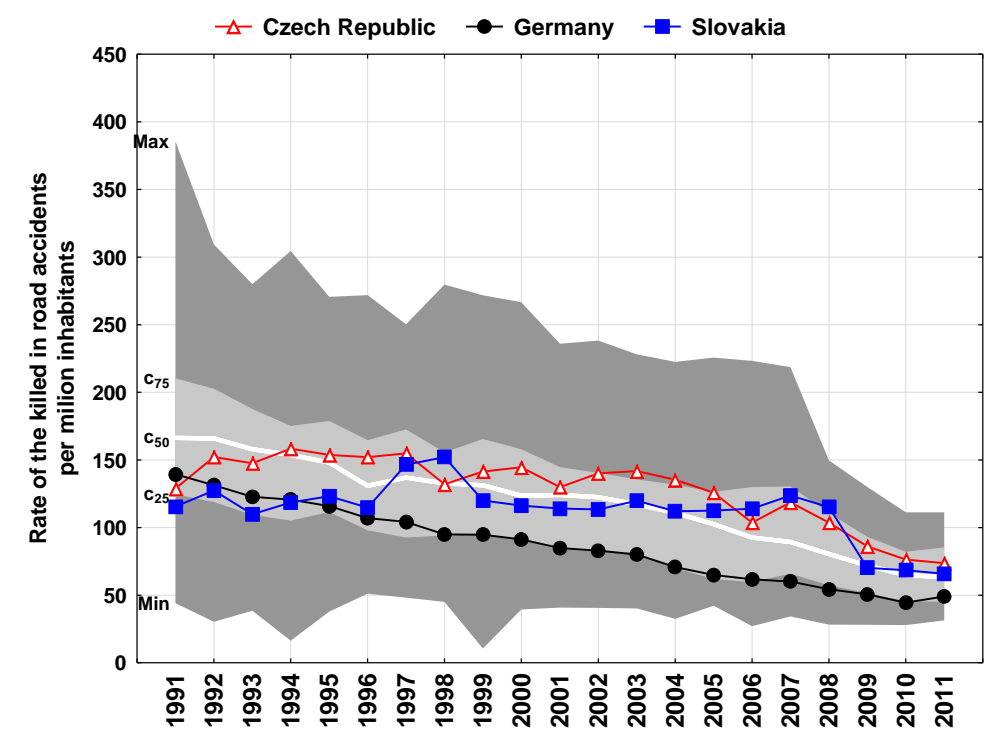

Source: own study

Systematic, almost perfectly linear decreasing trend rate of the road fatalities per million inhabitants characterizes Germany (Fig. 6). The pace of improvement in the situation on the road in this country is not in any significant way higher than average in the European countries. In both 1991 and 2011 the country was slightly above 25 percentile rate for all European countries. In Slovakia, life-threatening death in a road accident had increased significantly in 1997 and remained at the level of the center and in some years even at the level of 75 percentile of results for all the EU countries. Only in the last three years covered by the analysis we can observe a significant improvement on Slovak roads. Safety on roads in the Czech Republic started to grow only since 2002, and since then we can observe a slow decline in the rate of road accidents casualties. The pace of these changes in the Czech Republic is similar to most EU countries.

\section{CONCLUSIONS}

The development of road transport is a very positive and desirable phenomenon but it is associated with the increased risk on the roads which result in socioeconomic losses.

Considering three values describing the dangers of road safety, namely: the number of accidents, the number of injured and fatalities, huge discrepancies in the level of these values within some countries can be noticed. This issue was examined in more detail in subsection 4. The obtained results allow to consider data on the number of accidents and the number of people injured incomparable in the international section, probably for definitional reason. This is an important conclusion which calls into a question the value of quite popular in the media information about the so called rate of severity of road 
accidents $^{14}$ and its very high value in Poland (allegedly exceeding several times the level for the majority of the EU countries). Meanwhile, the level of this rate is determined mainly by differences in the definition of a road accident, which causes the situation that the road incident classified as an accident in one country does not have to be the same assessed in the other country.

Analyses show that in the most EU countries there is a systematic improvement of road safety. The pace of these changes is not the same in different countries. Unfortunately, one of the countries in which the improvement of the situation on the roads in the years 1991-2011 followed very slowly is Poland.

Presented article is a part of a series of publications which will examine the issues of road safety in international terms. In subsequent work there will be analyzed issues such as:

- searching for factors determining the different results of road accidents in the EU countries among the features describing the level of development of road infrastructure, the level of motorization or natural conditions;

- diversification of road safety at a regional level (NUTS-2) taking into account the spatial correlation;

- linking the threat of accidents with road traffic regulations operating in particular countries.

\section{REFERENCES}

[1] The Global Competitiveness Report 2011-2012 [2011], World Economic Forum, Geneva, Switzerland.

[2] Jaździk-Osmólska A. [2012], Metodologia i wycena kosztów wypadków drogowych na sieci dróg w Polsce na koniec roku 2011, Instytut Badawczy Dróg i Mostów, Warszawa.

[3] Popiel J. [2012], Koszty wypadków drogowych w wybranych krajach Unii Europejskiej, Transport Samochodowy 4.

[4] Sobolewski M. [2012], Road safety in Poland in the years 1998-2011, The Rzeszow University of Technology Publishing, Scientific Research Papers of The Faculty of Management, z. 19 (4), p. 153-160.

\section{ANALIZA ZMIAN W ZAKRESIE ŚMIERTELNOŚCI W RUCHU DROGOWYM W PAŃSTWACH UNII EUROPEJSKIEJ W LATACH 1991-2011}

W artykule przedstawiono wyniki czasowo-przestrzennej analizy wybranych aspektów bezpieczeństwa ruchu drogowego w państwach Unii Europejskiej. Horyzont badania obejmował lata 1991-2011. Dane do analiz pozyskane zostały z baz EUROSTAT-u i dotyczyły liczby wypadków oraz liczby osób zabitych i rannych w wypadkach drogowych. Wartości surowe tych cech przekształcono na wskaźniki natężenia względem liczby mieszkańców. W dalszej części pracy przedstawiono, w formie graficznej rankingi państw unijnych według bezpieczeństwa ruchu drogowego w roku 2011 bazując na wskaźniku liczby wypadków, liczby rannych oraz zabitych względem liczby mieszkańców. Ponieważ rankingi te charakteryzowały się bardzo niskim podobieństwem wyników, dokonano krytycznej oceny wiarygodności danych dotyczących liczby wypadków i liczby osób

\footnotetext{
${ }^{14}$ The rate of severity of road accidents is defined as the number of people killed in 100 road accidents. It is obvious that this rate will be low in countries in which the definition of road accident is wider (e.g. in Germany).
} 
rannych publikowanych przez EUROSTAT. W szczególności wykazano, iż dane te są nieporównywalne i nie mogą być przedmiotem rzetelnej analizy międzynarodowej. Przyczyną tego faktu są znaczące różnice w definicji osoby rannej a co za tym idzie samego wypadku drogowego. Płynie stąd ważny wniosek, iż wszelkie porównania międzynarodowe muszą być oparte na wskaźniku liczby zabitych w wypadkach drogowych. Uwzględniające aspekt czasowy badanego zjawiska, dla każdego państwa oceniono kierunek i tempo zmian wskaźnika zabitych w wypadkach w latach 1991-2011, wykorzystując w tym celu modele trendu liniowego. W bardziej szczegółowy sposób przeanalizowano poziom bezpieczeństwa ruchu drogowego w Polsce i w krajach ościennych - Niemczech, Słowacji, Czechach i na Litwie.

Słowa kluczowe: bezpieczeństwo ruchu drogowego, analiza czasowo-przestrzenna, trendy.

\section{DOI: 10.7862/rz.2013.mmr.32}

Tekst złożono w redakcji: wrzesień 2013

Przyjęto do druku: wrzesień 2013 